\title{
Chironomidae (Insecta, Diptera) from Alto Paranapanema Basin, SOUTHEASTERN BRAZIL
}

\author{
Kathia Sonoda $^{1 *}$, Juaci Malaquias ${ }^{1}$, Carlos Vettorazzi $^{2}$ \\ ${ }^{1}$ Embrapa Cerrados, Rod BR 020 km 18, Caixa Postal 08223, CEP 73310-970, Planaltina, DF, Brazil \\ E-mails: kathia.sonoda@,cpac.embrapa.br,juaci.malaquias@cpac.embrapa.br \\ ${ }^{2}$ ESALQ. Av. Pádua Dias, 11. Caixa Postal 9. CEP 13418-900. Piracicaba, SP, Brazil \\ E-mail: cavettor@esalq.usp.br \\ *Correspoding author
}

\begin{abstract}
We investigated the community of Chironomidae from three rivers belonging to the same river basin in Southern Brazil. Our objective was to analyze if the Chironomidae communities from rivers of the same basin were similar and relate this to land-use and water quality variables. Samples of insects were taken using artificial substrate baskets and left 44 days in the field for colonization during the dry season in 2002. Study reaches with the relevant land-use category present for at least $500 \mathrm{~m}$ along both river banks above and alongside the study reach were selected and land-use, terrain slope of the river basin and chemical and physical variables of the water were analysed. Faunal data were analyzed by number of individuals, richness of genera and community indices. Statistical analyses were performed in order to investigate the relationship between abiotic variables and the Chironomidae communities. Twenty-two genera were identified; Rheotanytarsus (Thienemann \& Bause) was the most abundant in all assemblages. Some genera showed preferences in their distribution, and were observed in only one of the rivers. Land-use and slope of the terrain were similar for all rivers, while the water quality variables were different for the Taquari River compared to the two other sites. This may explain the differences in the Chironomidae community observed for this locality.
\end{abstract}

\section{Introduction}

The ever increasing human population has induced a need for more agricultural land to provide food and sources for bioenergy. The Southeastern Brazilian region is now over-exploited as a result of recent deforestation (also of the riparian forests) and replacement by crop plantations or pastureland for cattle (Loureiro 1998).

The importance of the riparian forest to aquatic systems and their biota has been described extensively (Casatti et al. 2006; Matthaei et al. 2006).
The usual conclusions in such studies focus on the negative aspect of the conversion of riparian forest to agricultural land (Cetra and Petrere 2007; Galbraith et al. 2008). Their presence is important for the maintenance of temperature equilibrium, as continous food supply for aquatic animals, as source of organic material and stabilization of stream banks (Marinho Filho and Reis 1989; Rodrigues 1992; Aguiar et al. 2002).

Because of their widespread distribution and the sensitiveness to pollution observed for some species, chironomids are used worldwide as biological indicators of environmental quality (Bacey and Spurlock 2007; Chessman et al. 2007; Smith et al. 2007). Several projects around the world demonstrate their application as bioindicators (WRC 2001; MDFRC 2007).

In Brazil, several studies have been conducted in order to analyse the influence of the surrounding land-use on the aquatic fauna (Sonoda 2005; Corbi and Trivinho-Strixino 2008). The interaction of terrestrial and aquatic systems is often analysed in small watersheds in an attempt to reduce the influence of extraneous environmental factors that, consequently, make it more difficult to detect the effects of differences in catchment landuse (Siqueira and Trivinho-Strixino 2005; Roque et al. 2008). Studies conducted on large Brazilian aquatic systems are rare in the scientific literature; as the velocity of river flow and sudden changes in the water level are some of the difficulties encountered.

As stated by Vinson and Hawkins (2003), streams within similar biomes support similar number of taxa. This implies that the physical and biological environment of streams are a strong selective force on insect stream communities.

The rivers studied here are similar with regard to land-use and cover, terrain slope, river channel morphology and climate. Our objective was to analyze if the Chironomidae communities from 


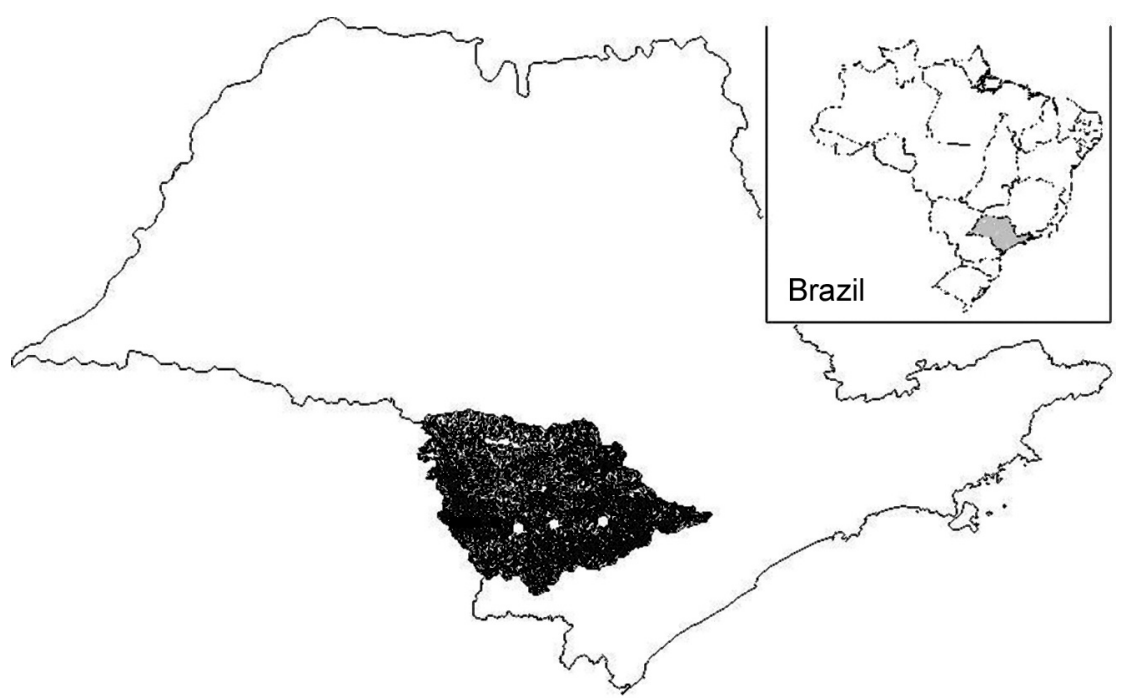

Figure 1. Map of São Paulo State, with the location of the sampling sites (white dots). The insert shows the location of São Paulo State in Brazil.

rivers of the same basin were similar and if possible to explain reasons for differences if these were found.

\section{Material and Methods}

Study Area

Our study was carried out in the Alto Paranapanema River basin, State of São Paulo (Brazil) (Figure 1), which has a drainage area of 22,550 $\mathrm{km}^{2}$. The rivers selected for the study were Paranapanema, Apiaí-Guaçu and Taquari; a description of the sampling sites is given in Table 1 .

Based on previous methodological studies (Lammert and Allan 1999; Solimini et al. 2000; Cuffney et al. 2002), the following criterion was used when selecting our study reaches: the land-use analyzed (pasture or forest) had to be present for at least 500 $\mathrm{m}$ length along both river banks, both above and alongside each study reach (Figure 2).

Sampling procedure

Six baskets $(30 \mathrm{~cm} \times 15 \mathrm{~cm} \times 8 \mathrm{~cm}$, mesh size 2.0 $\mathrm{cm})$ filled with artificial substrates [clay rocks of particle size 16-32 mm, classified as coarse gravel after Gordon et al. (1992)] were placed under water along the river banks during the dry season. After the 44 days of colonization, the baskets were removed, placed in $80 \%$ alcohol and carried to the laboratory. There, they were washed under flowing water over a sieve of mesh size of $0.2 \mathrm{~mm}$. The chironomid larvae were sorted and identified to genus following the key provided by TrivinhoStrixino and Strixino (1995).

Land-use and water quality variables

LANDSAT imagery was used to generate digital maps from which percentages of land-use distribution and terrain slopes upstream of the sampling areas were calculated.

Chemical and physical variables were surveyed by Salomão (2004) who analyzed the following water variables: fine suspended solids (FSS), coarse suspended solids (CSS), total suspended solids (TSS), water temperature, $\mathrm{pH}$, conductivity, dissolved oxygen, dissolved organic carbon, dissolved inorganic carbon, free $\mathrm{CO}_{2}$, chloride, $\mathrm{NO}_{2}, \mathrm{NO}_{3}, \mathrm{NH}_{4}$, $\mathrm{SO}_{4}, \mathrm{Na}, \mathrm{K}, \mathrm{Mg}$, Ca (Table 2).

Data analysis

The chironomids were analyzed as total number and percentage of individuals per genus, number of genera, taxon richness, Shannon-Wiener's diversity index, Margalef's richness, evenness index (Odum 1984; calculated using 2 as the base for the logarithm) and Sørensen's modified index (Dise-

Table 1. Basic description of the sampling sites in the Alto Paranapanema River Basin.

\begin{tabular}{|l|ccc|}
\hline Parameter & Paranapanema River & Apiaí-Guaçu River & Taquari River \\
\hline Area of sub-basins $\left(\mathrm{km}^{2}\right)$ & 710.39 & 899.74 & 828.08 \\
Depth (m) & 0.5 & 1.4 & 1.8 \\
Width (m) & 17.5 & 15 & 17 \\
Latitude & $23^{\circ} 90^{\prime} 79^{\prime}$ & $23^{\circ} 93^{\prime} 11^{\prime \prime}$ & $23^{\circ} 96^{\prime} 91^{\prime \prime}$ \\
Longitude & $48^{\circ} 25^{\prime} 96^{\prime}$ & $48^{\circ} 65^{\prime} 78^{\prime \prime}$ & $48^{\circ} 94^{\prime} 61^{\prime \prime}$ \\
\hline
\end{tabular}



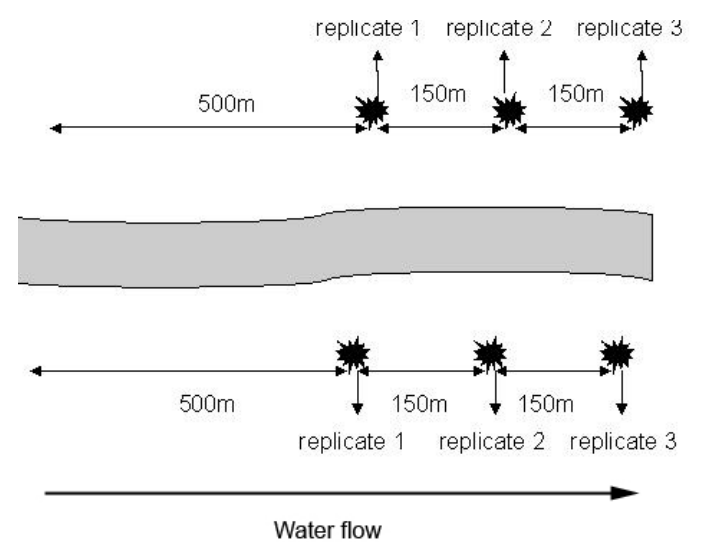

Figure 2. Schematic drawing of the experimental design in each of the three rivers. Colonisation baskets were placed along both river margins at each of the three sampling points at all study sites.

rud and Ødegaard 2007) that permits the integrated analysis of all sites.

The $\mathrm{X}^{2}$ test was used to analyze the influence of location (rivers) on individual abundance and diversity indices. We utilized Pearson's correlation and two-way ANOVA to integrate abiotic and biotic data, to analyze the interactions among them. All statistical analyses were performed using $\mathrm{SAS} \circledast$ (version 9.1.2, The SAS Institute, Cary, NC) (Wright and Covich 2005).

\section{Results}

Watershed and water features

The analysis of land-use and terrain-slope showed similar patterns at the sampled rivers within the watershed (Table 2); native vegetation was the main land-use followed by pasture and areas of reforestation. The percentage of the adjacent landuse was slightly different for the Apiaí-Guaçu River, showing the least reforestation $(6.2 \%$ of the area) and the most pasture land-use (39\%) when compared to the other rivers (Table 2).

The slopes were divided into seven classes with

Table 2. Main land-use and main slope-class of the river sub-basins upstream of the sampling sites.

\begin{tabular}{|l|ccc|}
\hline $\begin{array}{l}\text { Land-use/ } \\
\text { terrain-slope }\end{array}$ & $\begin{array}{c}\text { Parana- } \\
\text { panema }\end{array}$ & $\begin{array}{c}\text { Apiaí- } \\
\text { Guaçu }\end{array}$ & Taquari \\
\hline Pasture & $22.6 \%$ & $39 \%$ & $25.3 \%$ \\
Native & $56.7 \%$ & $43.7 \%$ & $47.2 \%$ \\
vegetation & & & \\
Reforestation & $16.2 \%$ & $6.2 \%$ & $17.9 \%$ \\
$<2 \%$ & $21.4 \%$ & $23.2 \%$ & $21.1 \%$ \\
$5 \%-10 \%$ & $14.1 \%$ & $13.4 \%$ & $13 \%$ \\
$10 \%-15 \%$ & $16.4 \%$ & $12.7 \%$ & $17.7 \%$ \\
$15 \%-45 \%$ & $41 \%$ & $40.3 \%$ & $41.9 \%$ \\
\hline
\end{tabular}

the four most common are shown in table 3. All rivers showed similar values with $40-42 \%$ of the area upstream of the sampling sites belonging to the fourth class ( $15 \%$ to $45 \%$ slope). About $22 \%$ of the area belonged to the first class with less than $2 \%$ slope.

Despite the similarities in land-use and terrainslope, the chemical and physical variables of the sampled rivers (Table 3) showed great differences with higher values for most variables in the Taquari River. The ANOVA identified significant differences in some of the water quality variables between sites and identified $\mathrm{SO}_{4}, \mathrm{Na}, \mathrm{FSS}, \mathrm{CSS}$, and TSS as characteristic for the Taquari River.

The Paranapanema River showed the lowest values for most variables, the ones which showed statistically significant differences to the other sites and characterized the river were $\mathrm{pH}, \mathrm{CO}_{2}, \mathrm{NO}_{2}$ and $\mathrm{Cl}$. Variables such as conductivity, $\mathrm{DIC}, \mathrm{HCO}_{3}$, $\mathrm{NO}_{3}, \mathrm{~K}, \mathrm{Mg}, \mathrm{Ca}$ showed statistical significant differences between all the rivers.

Chironomidae fauna

A total of 2,642 individuals of Chironomidae were collected, comprising twenty-two genera. The highest number of individuals was collected at the Paranapanema River (1,065 specimens). The generic richness was quite similar at the three sites with seventeen genera collected from both the

Table 3. Values of chemical and physical variables of water from the rivers studied (sed $=$ sediment).

\begin{tabular}{|c|c|c|c|}
\hline Parameter & $\begin{array}{l}\text { Parana- } \\
\text { panema }\end{array}$ & $\begin{array}{l}\text { Apiaí- } \\
\text { Guaçu }\end{array}$ & Taquari \\
\hline FSS (mg sed/L) & 8.0 & 28.3 & 93.7 \\
\hline CSS (mg sed/L) & 1.0 & 3.3 & 13.4 \\
\hline TSS (mg sed/L) & 9.0 & 31.7 & 107.1 \\
\hline TEMP $\left({ }^{\circ} \mathrm{C}\right)$ & 19.6 & 19.8 & 20.1 \\
\hline $\mathrm{PH}$ & 6.5 & 7.3 & 7.3 \\
\hline $\operatorname{COND}(\mu \mathrm{S} / \mathrm{cm})$ & 31.0 & 81.0 & 111.7 \\
\hline OD (mg/L) & 8.5 & 8.6 & 8.1 \\
\hline DOC (mg/L) & 4.5 & 4.9 & 4.0 \\
\hline $\mathrm{DIC}(\mathrm{mg} / \mathrm{L})$ & 7.3 & 32.3 & 40.0 \\
\hline $\mathrm{Cl}(\mu \mathrm{M})$ & 96.7 & 53.7 & 50.5 \\
\hline $\mathrm{NO}_{2}(\mu \mathrm{M})$ & 0.0 & 22.1 & 23.8 \\
\hline $\mathrm{NO}_{3}(\mu \mathrm{M})$ & 19.0 & 14.6 & 29.2 \\
\hline $\mathrm{SO}_{4}(\mu \mathrm{M})$ & 8.0 & 11.9 & 75.2 \\
\hline $\mathrm{Na}(\mu \mathrm{M})$ & 110.3 & 99.8 & 218.1 \\
\hline $\mathrm{NH}_{4}(\mu \mathrm{M})$ & 1.0 & 0.6 & 1.9 \\
\hline $\mathrm{K}(\mu \mathrm{M})$ & 13.4 & 34.1 & 50.4 \\
\hline $\operatorname{Mg}(\mu \mathrm{M})$ & 36.6 & 129.0 & 156.9 \\
\hline $\mathrm{Ca}(\mu \mathrm{M})$ & 33.0 & 196.8 & 258.7 \\
\hline
\end{tabular}


Paranapanema River and the Apiaí-Guaçu River; and 15 genera from the Taquari River (Table 4).

Chironominae was the sub-family with highest number of individuals and also the greatest taxon richness; Tanytarsini was the most abundant tribe in all rivers. This was due to the high number of Rheotanytarsus, the numerically dominant genus, always representing more than $59 \%$ of the assemblages and reaching $71.4 \%$ in the Taquari River. In contrast, Procladiini was the rarest tribe represented only by two individuals belonging to Djalmabatista at the Apiaí-Guaçu River.

At the Paranapanema River, Nanocladius and Ablabesmyia were frequent too, and at the ApiaíGuaçu River, Nanocladius was the second most abundant genus after Rheotanytarsus (Table 4).

Some genera were rare in all environments: Chironomus and Endotribelos were sampled only at the Paranapanema River, while Tribelos and Djalmabatista were found exclusively at the ApiaíGuaçu River. The Taquari River had no unique taxa.

The communities from the Paranapanema River

Table 4. Relative distribution (\%) of genera in each community.

\begin{tabular}{|l|c|c|c|}
\hline Genus & $\begin{array}{c}\text { Parana- } \\
\text { panema }\end{array}$ & $\begin{array}{c}\text { Apiaí- } \\
\text { Guaçu }\end{array}$ & Taquari \\
\hline Beardius & 2.35 & 3.71 & 0.33 \\
Chironomus & 0.56 & 0.00 & 0.00 \\
Endotribelos & 0.09 & 0.00 & 0.00 \\
Fissimentum & 0.28 & 0,00 & 4.10 \\
Goeldichironomus & 0,00 & 0.15 & 0.00 \\
Harnischia & 0.85 & 0.15 & 1.33 \\
Lauterborniella & 1.97 & 1.19 & 0.00 \\
Parachironomus & 0.00 & 0.15 & 0.11 \\
Pol. (Asheum) & 3.85 & 0.59 & 0.33 \\
Pol. (Polypedilum) & 0.00 & 1.34 & 1.99 \\
Stenochironomus & 0.09 & 0.00 & 0.11 \\
Tribelos & 0.00 & 0.30 & 0.00 \\
Rheotanytarsus & 59.81 & 59.50 & 71.43 \\
Corynoneura & 3.38 & 4.15 & 3.54 \\
Lopescladius & 0.19 & 0.00 & 1.33 \\
Nanocladius & 10.33 & 16.77 & 3.32 \\
Ablabesmyia & 11.27 & 1.48 & 9.63 \\
Labrundinia & 2.54 & 8.01 & 1.11 \\
Larsia & 0.19 & 0.15 & 0.22 \\
Nilotanypus & 0.85 & 0.59 & 0.00 \\
Pentaneura & 1.41 & 1.48 & 1.11 \\
Djalmabatista & 0.00 & 0.30 & 0.00 \\
\hline
\end{tabular}

Table 5. Biotic indices of the communities from the three rivers.

\begin{tabular}{|l|l|l|l|}
\hline River & Diversity & Richness & Evenness \\
\hline $\begin{array}{l}\text { Parana- } \\
\text { panema } \\
\text { Apiaí- } \\
\text { Guaçu } \\
\text { Taquari }\end{array}$ & 0.74 & 1.59 & 0.18 \\
\hline
\end{tabular}

and the Apiaí-Guaçu River had similar values for diversity and evenness indices (Table 5), the differences seen in the richness index was due to the greater number of individuals in the Paranapanema assemblage. Taquari's community showed lower values for all indices due to the marked dominance of Rheotanytarsus. The Sørensen's modified similarity index indicated a medium level of similarity among communities from the three rivers $(S=0.55)$.

\section{Discussion}

Watershed and water features

As the aquatic ecosystems are tightly coupled with their catchments (Maloney et al. 2008, Lamberti et al. 2010), the selection of three rivers from the same basin permitted us to minimize variation in catchment-scale features such as surrounding land-use, terrain-slope, climatic conditions, and channel morphology. Such variation can confound the influence of water quality on the aquatic biota and should be eliminated if possible. Some studies have emphasised the great importance of land cover as the main factor defining the structure of the aquatic entomofauna (e.g. Corbi and TrivinhoStrixino 2008). Our analysis of land-use upstream of the sampling sites (Table 2) showed minimal differences among the rivers and led us to believe that the dissimilarity in chironomid community structure was influenced by other factors.

Despite similarities in catchment features, water quality variables showed great differences between the rivers, where the Taquari River showed higher values of $\mathrm{NO}_{3}, \mathrm{SO}_{4}, \mathrm{~K}, \mathrm{Mg}, \mathrm{Na}$ and $\mathrm{Ca}$ (Table $3)$. Conductivity is highly influenced by a range of chemical variables. For the Taquari River, sodium, magnesium and calcium ions were the ones with highest concentrations, however, the statistical analysis only returned a positive association of sulphate to this river. High values of limestone and sulphate are recorded in the soil surrounding the Alto Paranapanema River basin (Milléo et al. 2008; CPRM 2009) and this might explain the high values of calcium ions and sulphate measured there. 
There is restricted urban development in the area, thus, the main source for the high levels of ions probably is related to local agricultural practice. However, additional studies probably should be conducted to explore the source of the high ionlevel at this site. The high level of TSS at the Taquari site probably is not controlled by land-use as the watershed showed the same percentage of forest cover as the Paranapanema River, where the quantity of suspended solids was significantly lower (10\% of the TSS recorded at Taquari).

Chironomidae fauna

The subfamilies Chironominae, Orthocladiinae and Tanypodinae are quite common in Neotropical streams (Sanseverino and Nessimian 2008). The Chironominae frequently are described as the most abundant Chironomidae subfamily in the region (Suriano and Fonseca-Gessner 2004; Trivinho-Strixino and Strixino 2005; Mendes and Pinho 2009) while Orthocladiinae is the most common subfamily in lotic systems with high frequency in rapids of streams and rivers (Coffman and Ferrington 1984, 1996).

The genus Rheotanytarsus, showed numerical dominance in all three rivers, with a remarkable abundance of individuals at the Taquari River; however no statistical significant correlation to any water variable was made that could explain the high abundance. The reason for the high abundance is not quite clear, but authors have found a positive relationship of the genus to high pollution level (Simião-Ferreira et al., 2009) of water bodies at Anápolis (GO) in the Brazilian Cerrado biome. On the other hand, authors have also established a direct correlation of its presence to good water-quality environments (Corbi and TrivinhoStrixino, 1999). It is described as typical of lotic environments and prefers rapid flux water due to its filtering habits (Higuti and Takeda, 2002).

A high abundance of Rheotanytarsus was also recorded by Sonoda et al. (2009) in the study of the influence of land-use on the chironomid fauna of rivers of São Paulo State, Southeastern Brazil. In this study, the high abundance of Rheotanytarsus showed no correlation to land-use, occurring in rivers with both adjacent forests and pasture-land. Hepp et al. (2008) also recorded a high proportion of Rheotanytarsus in rivers of southern Brazil. In contrast, Jorcin and Nogueira (2008) found no Rheotanytarsus but a high number of Djamabatista in the waterfall of the Paranapanema reservoir. A high abundance of Djamabatista larvae was also recorded by Trivinho-Strixino and Strixino (2005) who analyzed the Chironomidae community in the
Ribeira River, spatially near the Paranapanema River Basin. Djamabatista larvae are good swimmers and prefer shallow water (Nessimian and Henriques-de-Oliveira 2005). As the rivers here studied showed no waterfall and rapids, this might explain why larvae of this genus were relatively rare in our study where only two individuals were sampled in the Apiaí-Guaçu River.

As seen in our study, once the main landscape variables are fixed the observed divergence in the chironomid communities can be associated with significant differences in water quality variables. A genus that exemplifies this relationship well is Nilotanypus. The genus is considered to be intolerant to pollution (Smith and Cranston 1995) and its absence from the Taquari River could be a response to the poorer water quality at this site. Some Brazilian studies has shown how water quality variables can influence the entomofauna. Melo (2009) found distinctly different macroinvertebrate communities in nearby sites (streams) in Southeastern Brazil and concluded that these were a result of different levels of conductivity and stream size (orders). Futhermore, Roque et al. (2010) analyzed the Chironomidae fauna from 61 streams and discussed the importance of both local (conductivity) and broad (riparian forest cover) scales on the aquatic community composition in streams of São Paulo State. They observed a negative relationship between the percentage of riparian forest and generic diversity. Similar results have been reported from analyses of land-use and macroinvertebrate diversity in southeastern Brazil (Corbi 2006; Corbi and Trivinho-Strixino 2006; Sonoda et al. 2009).

A lower generic richness and a dominance of only one taxon was observed at the Taquari River. Such characteristics are often observed in impacted systems (Stone et al. 2005) and influence the values of biotic indices. This is also seen in our results (Table 5). The use of diversity and richness indices as appropriate metrics to evaluate stream conditions is defended by Suriano et al. (2010) who analyzed 49 metrics to assess the conditions of streams of São Paulo State. Similarity measures are among the most common (and accepted) metrics for comparing sites or samples (Diserud and Ødegaard 2007). The value of the Sørensen index indicated a medium degree of difference among the communities analysed here.

In conclusion, this study demonstrates that rivers belonging to the same basin, with similar land characteristics may not necessarily support similar midge communities and that poorer water quality can be reflected in the chironomid community. 


\section{Acknowledgments}

We gratefully acknowledge the contributions of the following institutions or individuals to our research project: Dr Marcos Salomão for data on water quality variables, Dr Alexandre Silva, Dr Silvio Ferraz, Dr. Roberta Valente for landusedata and GIS consulting, professor Susana Trivinho-Strixino for the identification of Tanypodinae specimens, FAPESP (State of São Paulo Research Foundation) through the Biota/FAPESP Program (Proc. $N^{\circ}$ 00/14242-6). We also acknowledge two anonymous reviewers and Dr. Torbjorn Ekrem for their comments and suggestions that contributed substantially to the improvement of this manuscript.

\section{References}

Aguiar, F. C., Ferreira, M. T. and Pinto, P. 2002. Relative influence of environmental variables on macroinvertebrate assemblages from an Iberian basin. - J. N. Am. Benthol. Soc. 21(1): 43-53.

Bacey, J. and Spurlock, F. 2007. Biological assessment of urban and agricultural streams in the California Central Valley. - Environ. Monit. Ass. 130: 483-493.

Casatti, L., Langeani, F., Silva, A. M. and Castro, R. M. C. 2006. Stream fish, water and habitat quality in a pasture dominated basin, Southeastern Brazil. - Brazil. J. Biol. 66(2B): 681696.

Chessman, B., Williams, S. and Besley, C. 2007. Bioassessment of streams with macroinvertebrates: effect of sampled habitat and taxonomic resolution. - J. N. Am. Benth. Soc. 26(3): 546565.

Cetra, M. and Petrere Jr, M. 2007. Associations between fish assemblage and riparian vegetation in the Corumbataí River Basin (SP). - Brazil. J. Biol. 67(2):191-195.

Coffman, W. P. and Ferrington Jr, L. C. 1984. Chironomidae. In: Merritt RW, Cummins KW (eds) An introduction to the aquatic insects of North America, 2nd ed. Pp.551-562. Kendall Hunt Publishing Co, Dubuque.

Coffman, W. P. and Ferrington Jr, L. C. 1996. Chironomidae. In: Merritt RW, Cummins KW (eds.). An introduction to the aquatic insects of North America, 3rd ed. Pp.635- 754. Kendall Hunt Publishing Co, Dubuque.

Corbi, J. J. 2006. Influência de práticas de manejo de solo sobre os macroinvertebrados aquáticos de córregos: ênfase para o cultivo de cana-deaçúcar. PhD Dissertation, Universidade Federal de São Carlos, São Carlos, SP, Brazil. 93p.

Corbi, J. J. and Trivinho-Strixino, S. 1999. Chironomidae (Diptera) e outros macroinvertebrados em rios sob influência de cultura canavieira (Araraquara - SP). In: Encontro Brasileiro sobre Taxonomia e Ecologia de Chironomidae, 3. Resumos. Rio de Janeiro: Instituto Oswaldo Cruz. s.p.

Corbi, J. J. and Trivinho-Strixino, S. 2006. Influence of taxonomic resolution of stream macroinvertebrate communities on the evaluation of different land uses. - Acta Limnol. Brasil. 18: $469-475$.

Corbi, J. J. and Trivinho-Strixino, S. 2008. Effects of land use on lotic chironomid communities of Southeast Brazil: emphasis on the impact of sugar cane cultivation. - Boll. Mus. Munic. Funchal 13:93-100.

CPRM, 2009. Serviço Geológico do Brasil. Ministério de Minas e Energia. Alto Paranapanema. http://www.cprm.gov.br/publique/cgi/cgilua. exe/sys/start.htm?infoid $=1229 \&$ sid $=9$ Accessed on: 25 Oct 2010.

Cuffney, T. F., Gurtz, M. E. and Meador, M. R. (Eds) 2002. Methods for collecting benthic invertebrate samples as part of the National Water-Quality Assessment Program. US Geological Survey. http://www.usgs.org, accessed 19 Jan 2010.

Diserud, O.H. and Ødegaard, F. 2007. A multiplesite similarity measure. - Biol. Lett. 3: 2-22.

Galbraith, H. S., Vaughn, C. C. and Meier, C. K. 2008. Environmental variables interact across spatial scales to structure trichopteran assemblages in Ouachita Mountain rivers. - Hydrobiologia 596: 401-411.

Gordon, N. D., McMahin, T. A. and Finlayson, B. L. 1992. Stream hydrology. An introduction for ecologists. John Wiley and Sons, Chichester. $526 \mathrm{p}$.

Hepp, L. U., Biasi, C.; Milesi, S. V., Veiga, F. O. and Restello, R. M. 2008. Chironomidae (Diptera) larvae associated to Eucalyptus globulus and Eugenia uniflora leaf litter in a subtropical stream (Rio Grande do Sul, Brazil). - Acta Limnol. Brasil. 20(4): 345-350.

Higuti, J. and Takeda, A. M. 2002. Spatial and temporal variation in densities of chironomid larvae (Diptera) in two lagoons and two tribu- 
taries of the Upper Paraná River floodplain, Brazil. - Brazil. J. Biol. 62(4B): 807-818.

Jorcin, A. and Nogueira, M. G. 2008. Benthic macroinvertebrates in the Paranapanema reservoir cascade (Southeast Brazil). - Brazil. J. Biol. 64(4, suppl.): 1013-1024.

Lamberti, G. A., Chaloner, D. T. and Hershey, A. E. 2010. Linkages among aquatic ecosystems. - J. N. Am. Benth. Soc. 29(1): 245-263.

Lammert, M. and Allan, J. D. 1999. Assessing biotic integrity of streams: effects of scale in measuring the influence of land use/cover and habitat structure on fish and macroinvertebrates. - Environ. Man. 23: 257-270.

Loureiro, W. 1998. Incentivos econômicos para conservação da biodiversidade no Brasil. $\mathrm{Cu}-$ ritiba, PR. SEMA/IAP. s.p.

Maloney, K. O., Feminella, J. W., Mitchell, R. M., Miller, S. A., Mulholland, P. J. and Houser, J. N. 2008. Land use legacies and small streams: identifying relationships between historical land use and contemporary stream conditions. - J. N. Am. Benth. Soc. 27(2): 280-294.

Matthaei, C. D., Weller, F., Kelly, D. W. and Townsend, C. R. 2006. Impacts of fine sediment addition to tussock, pasture, dairy and deer farming streams in New Zealand. - Freshw. Biol. 51: 2154-2172.

Marinho Filho, J. S. and Reis, M. L. 1989. A fauna de mamíferos associados às matas de galeria. In: Barbosa, L. M. (Coord.). Simpósio sobre mata ciliar. Anais. Campinas, SP. Fundação Cargil. Pp.43-60

MDFRC. (Murray-Darling Freshwater Research Centre) (2007) Macroinvertebrate survey. http://www.mdfrc.org.au/, accessed 16 Jun 2010.

Melo, A. S. 2009. Explaining dissimilarities in macroinvertebrate assemblages among stream sites using environmental variables. - Zoologia 26(1): 79-84.

Mendes, H. F. and Pinho, L. C. 2009. Chironomidae: Lista de espécies registradas para o Brasil e estados com registro de pelo menos uma espécie. http://sites.ffclrp.usp.br/aguadoce/chironomidae/Listatotal.htm, accessed 16 Jun 2010.

Milléo, M. Z., D'Oliveira, M. A. F., Ayub, D. F.; Mazzini, F. and Linder, C. (Eds.). 2008. Situação de Recursos Hídricos das Bacias Hidrográficas no Estado de São Paulo. Comitê da
Bacia Hidrográfica do Alto Paranapanema. 2009. 12p.

Nessimian, J. L. and Henriques-de-Oliveira, A. L. 2005. Colonização do "litter" de Eleocharis sellowiana Kunth. (Cyperaceae) por larvas de Chironomidae (Diptera) em um brejo no litoral do estado do Rio de Janeiro. - Ent. Vect. 12(2): 159-172.

Odum, E. P. 1984. Ecologia. Ed. Guanabara, RJ. $434 p$.

Rodrigues, R. R., Leitão Filho, H. F. and Crestana, M. C. 1992. Revegetação do entorno da represa de abastecimento de água do município de Iracemápolis, SP. In: Simpósio sobre Recuperação de Áreas Degradadas. Anais. Curitiba, PR. s.p.

Roque, F. O., Lecci, L. S., Siqueira, T. and Froehlich, C. G. 2008. Using environmental and spatial filters to explain stonefly occurrences in Southeastern Brazilian streams: implications for biomonitoring. - Acta Limnol. Brasil. 22(1): 35-44.

Roque, F. O., Siqueira, T., Bini, L. M., Ribeiro, M. C., Tambosi, L. R., Ciocheti, G. and TrivinhoStrixino, S. 2010. Untangling associations between chironomid taxa in Neotropical streams using local and landscape filters. - Freshw. Biol. 55: 847-865.

Salomão, M. S. M. B. 2004. Biogeoquímica de rios do Estado de São Paulo com bacias de drenagem apresentando diferentes características de ocupação do solo. PhD Dissertation, Universidade de São Paulo, Piracicaba, SP, Brazil. 125p.

Sanseverino, A. M. and Nessimian, J. L. 2008. Larvas de Chironomidae (Diptera) em depósitos de folhiço submerso em um riacho de primeira ordem da Mata Atlântica (Rio de Janeiro, Brasil). - Rev. Brasil. Ent. 52(1): 95-104.

Siqueira, T. and Trivinho-Strixino, S. 2005. Diversidade de Chironomidae (Diptera) em dois córregos de baixa ordem na região central do Estado de São Paulo, através da coleta de exúvias de pupa. - Rev. Brasil. Ent. 49(4): 531-534.

Simião-Ferreira, J., DeMarco Jr, P., Mazão, G. and Carvalho, A. R. 2009. Chironomidae assemblage structure in relation to organic enrichment of an aquatic environment. - Neotrop. Ent. 38(4): 464-471.

Smith, J., Samways, M. J. and Taylor, S. 2007. Assessing riparian quality using two complemen- 
tary sets of bioindicators. - Biodiv. Cons. 16: 2695-2713.

Smith, M and Cranston, P. S. 1995. "Recovery" of an acid mine-waste impacted tropical stream - the chironomid story. In: Cranston, P.S. (Ed.). Chironomids: from genes to ecosystems. CSIRO, Australia. Pp. 161-173.

Solimini, A. G., Gulia, P., Monfrinotti, M. and Carchini, G. 2000. Performance of different biotic indices and sampling methods in assessing water quality in the lowland stretch of the Tiber River. - Hydrobiologia 422/423:197-208.

Sonoda, K. C. 2005. Relação entre os diferentes usos da terra de entorno e a composição de insetos aquáticos de quatro bacias hidrográficas do Estado de São Paulo. PhD Dissertation, Universidade de São Paulo, Piracicaba, SP, Brazil. 124p.

Sonoda, K. C., Matthaei, C. R. and Trivinho-Strixino, S. 2009. Contrasting land uses affect Chironomidae communities in two Brazilian rivers. - Fund. App. Limnol. 174(2): 173-184.

Stone, M. L., Whiles, M. R., Webber, J. A., Williard, K. W. J. and Reeve, J. D. 2005. Macroinvertebrate communities in agriculturally impacted Southern Illinois streams: patterns with riparian vegetation, water quality, and instream habitat quality. - J. Environ. Qual. 34: 907-917.
Suriano, M. T. and Fonseca-Gessner, A. A. 2004. Chironomidae (Diptera) larvae in streams of Parque Estadual de Campos do Jordão, São Paulo State, Brazil. - Acta Limnol. Brasil. 16(2): 129-136.

Suriano, M. T., Fonseca-Gessner, A. A., Roque, F. O. and Froehlich, C. G. 2010. Choice of macroinvertebrate metrics to evaluate stream conditions in Atlantic Forest, Brazil. - Environ. Monit. Ass. DOI 10.1007/s10661-010-1495-3.

Trivinho-Strixino, S. and Strixino, G. 1995. Larvas de Chironomidae (Diptera) do Estado de São Paulo: guia de identificação e diagnose dos gêneros. PPG-ERN/ UFSCar, São Carlos. $230 \mathrm{p}$.

Trivinho-Strixino, S. and Strixino, G. 2005. Chironomidae (Diptera) do Rio Ribeira (divisa dos estados de São Paulo e Paraná) numa avaliação ambiental faunística. - Ent. Vect. 12(2): 243253.

Vinson, M. R. and Hawkins, C. P. 2003. Broadscale geographical patterns in local stream insect genera richness. - Ecography 26: 751767.

WRC (Water and rivers comMission) 2001. Water facts. 2nd ed.

Wright, M. S. and Covich, A. P. 2005. The effect of macroinvertebrate exclusion on leaf breakdown rates in a tropical headwater stream. Biotropica 37(3): 403-408. 